\title{
Reducing Classroom Disputes Between Faculty and Students
}

\author{
Ian N. Toppin I Laveda M. Pullens
}

Prior classroom management training makes a big difference in faculty's ability to handle disputes with students. This type

of training should be included in faculty orientation activities. The research presented in this article indicates that success

in dealing with behaviorally challenging students is possible if the likely areas of dispute are prepared for in advance. This

article will highlight some of the likely areas of dispute and strategies for addressing them, particularly in the following three

key areas: 1) Academic reasons why disputes occur between faculty and their students; 2) Non-academic reasons why dis-

putes occur between faculty and their students; and 3) Strategies for engaging students and reducing volatile incidences.

\section{INTRODUCTION}

A study involving 121 teachers from 11 public schools in the state of Virginia found that prior classroom management training makes a significant difference in those teachers' abilities to deal with incidences of student aggression (Alvarez, 2007). Therefore, it would be wise to include this type of training in faculty orientation activities. Increasing frequency of incidences of student aggression on college campuses highlight the fact that when students are granted admission to college their personalities and problems are not left behind. While the university in general may be unaware of those issues, faculty are often the ones left to deal with the fallout. In fact, some in the teaching profession would agree that dealing with behaviorally challenging students is one of the most dreaded and stressful aspects of their job.

Ignoring or even appeasing these students does not work. Therefore, strategies must be defined for engaging them. Success in dealing with behaviorally challenging students is possible if appropriate training is provided and the right strategies are used. This article will address some of those strategies while focusing on three key areas: 1) Academic reasons why disputes occur between faculty and their students; 2) Non-academic reasons why disputes occur between faculty and their students; and 3) Strategies for engaging students and reducing volatile incidences.

\section{ACADEMIC REASONS DISPUTES OCCUR BETWEEN FACULTY AND STUDENTS}

Lack of motivation - Lack of motivation may be defined as an absence of desire. Ebbeling and Van Brunt (2010) noted that managing students who lack motivation and appear to prefer to be any place other than the classroom is easier when faculty take the right stance. However, too often faculty take the position that college students are young adults and should be responsible for their own motivation. An article from Focus on Effectiveness (2005) reported that, 'Students' beliefs about their ability to learn are shaped by messages and experiences at home, at school, and in the larger society. Low expectations can be subtly communicated by parents and teachers, and through school practices such as tracking, ability grouping, or curriculum that is not challenging" (p. 1). Lack of motivation can stem from any of these external sources, but more importantly it produces deep-seated internal reservations and lack of drive, which often creates difficulties between faculty and students.

Disengagement - Disengagement is manifested through withdrawal behaviors. Harward (2008) observed that student disengagement can take many forms. For example, "when students avoid rigorous study, when students and faculty mutually agree to an "if you don't bother me, I won't bother you" compact, and when students and their families define education in terms of degree attainment - the cheaper and faster, the better" (p. 1). These events 
coalesce to provide tension between faculty and their students.

Signs of disengagement are more evident in traditional learning environments, especially among 'millennial' learners. These students have become comfortable with their technological tools and are easily bored in places where they are restricted from using them. Faculty who are unable or unwilling to incorporate such tools into their pedagogy, and who restrict students from using them, create an environment for disengagement. Radosevich \& Kahn's (2006) study, "Using Tablet Technology and Recording Software to Enhance Pedagogy" concluded that by implementing effective technology into a course, an instructor's teaching method can further enhance the learning environment and promote a student-centered learning atmosphere where the emphasis is on hands-on application rather than learning by lecture. This may further help to engage not only the 'millennial' learner but learners of all generations.

Even though online classroom environments may have more technological appeal, especially to millennial learners, faculty who teach in such environments are not exempted from the need to provide engaging activities. Online course design must appeal to multiple learning styles, especially since face-to-face cues of boredom and disengagement are absent. Faculty should be as actively involved in their online course as those who teach face-to-face courses are expected to be.

In 2006-2008 (NCES) National Center of Education Statistics, reported that 4.3 million $(20 \%)$ of undergraduates take at least one distance education course and .08 million (4\%) took their entire program through distance education. This trend has since grown significantly, but with these staggering numbers it is important for online instructors to seek effective ways to engage their students. Guidelines for class participation, thoughts and questions to initiate class discussion as well as collaborative assignments are all a part of effective strategies for student engagement in an online learning community (Palloff \& Pratt, 2007).

Financial pressures, family commitments, and employment obligations, along with life's other demands, also make it difficult for students to sustain a high level of engagement. This means that institutions of higher learning and their faculty must find creative ways to navigate around these challenges in order to increase the likelihood of their students being successful.

Academic Dishonesty - Cheating is a blatant sign of academic dishonesty. It is also a growing problem in the traditional as well as the online classroom, and since faculty are at the forefront of providing the main service for which students attend college, they are also saddled with the responsibility for policing them. The extent to which they are willing to perform this duty may depend on their personal perspectives on the issue. These perspectives vary from person to person, and the extent to which dishonesty is investigated varies proportionately among faculty. Some may care but view it as outside the realm of their job description.

In an article published by the Center for Teaching and Learning at the University of Minnesota at Mankato, it was reported that at least one-third $(1 / 3)$ of all college students admitted to cheating on an exam, half $(1 / 2)$ admitted to cheating on assignments, two-third (2/3) admitted seeing classmates cheat on exams and assignments, three-quarters $(3 / 4)$ believe cheating is not acceptable, and one-half $(1 / 2)$ believe that faculty do not try to catch cheaters (CETL, UM-Mankato, 2005).

To reduce academic dishonesty in online courses, some institutions have resorted to using proctored solutions, such as distributed testing centers and webcam technology for quality assurance with major assessment activities. A dissertation study by Chase (2010) found that there is a significant relationship between academic dishonesty in online courses and students' feelings of connectedness in the online classroom. The author asserted that where a sense of isolation exists students are more likely to be dishonest. Connectedness was encouraged through faculty's active interaction with students; through learning activities requiring application and critical thought, rather than memorization; through allowing students to critically analyze each other's work; and through sharing appropriate resources among students.

These results indicated that the scope of academic dishonesty may be so widespread that faculty who deal with it on a regular basis and whose moral framework is against it may find that aspect of their profession too exhausting to pursue. Either they surrender their moral position or deal with frustrations associated with students who persist in cheating. 
Disruptive Behavior - In this context, disruptive behaviors may be defined as those which deviate from established rules of conduct. A report from the Office of Educational Development at UC Berkley (2009) addressed specific disruptive behaviors and strategies for dealing with them. Those behaviors included: Talking in class, packing up early, arriving late/ leaving early, cheating, wasting time, asking problematic questions, showing disrespect, attending class irregularly, asking for extensions, and missing assignment deadlines (UC Berkley, Teaching, Learning, Academic Planning and Facilities, 2009). There are other disruptive behaviors, which could be added to this list such as: sleeping in class, unnecessary shuffling of papers, or other materials, and inappropriate use of disruptive mechanical devices such as cell phones, pagers, etc. Ultimately, these behaviors are all attempts to either monopolize or show disregard for the classroom and they can be irritating to faculty and other students. More importantly, they can negatively impact teaching and learning, and faculty's attitude toward their job.

This problem can be exacerbated in an online context where disruptive students can hide behind the security of virtual separation. This necessitates the need for clearly defined online etiquette and stated policies for dealing with violators. Policies should define how students are to conduct themselves in responding to blogs and discussion boards, and in communication with class-mates as well as with the professor.

Flirting - Flirting may be defined as unwanted sexual advances. A statement from the Counseling Center at Brookhaven College (2011) claims: "It is never comfortable to tell a student that he or she isn't being appropriate and if you are uncomfortable, a short, positive email, or phone call might suffice" (p. 4). Persistently unwelcomed sexual advances from students can be difficult situations for faculty to deal with. Institutions usually have rules governing how faculty are to conduct themselves in regard to extracurricular and intimate relations with their students. However, rules governing how students are to conduct themselves in an intimate manner with faculty are lacking. Hence, the frequency of students flirting with faculty is growing.

Grade Disputes - This is a common area of disruption in both traditional and online classrooms, even from students who may not be otherwise dis- ruptive. When graded assignments are returned and there is an apparent discrepancy between the assigned grade, and that which the student thought the grade should be, an adversarial climate can quickly emerge. Some appeals may be legitimate, but the troublesome ones are those which are made to coerce faculty into assigning grades students know they did not earn. Even though this can be a stressful situation, faculty have more control over it, and can resolve it more easily than some other types of disruptions. Grade disputes can usually be addressed through proper record-keeping, use of rubrics, and/ or clearly stated grading policies

Performance Concerns - A major area of conflict and difficulty with students in both traditional and online classrooms, have to do with their performance. Despite their conduct throughout the academic term, some students refuse to accept faculty's assessment of their performance. There are a number of reasons for this. For example, performance reports (grades) are a way of keeping students accountable to those who support their education. When the reports are not good, coercive actions are among the strategies students use to try to force faculty to comply with their efforts to conceal unfavorable results. This can also be true about high-performing students who for some reason find themselves in danger of losing scholarships, or some other form of financial aid. Obviously, there are students who are fully aware of the fact that their performance did not earn them the grade they seek, yet they become difficult in order to manipulate faculty into giving them the grade they desire. This is a frequent and stressful situation that faculty face.

\section{NON-ACADEMIC REASONS WHY DISPUTES OCCUR BETWEEN FACULTY AND STUDENTS}

Stress - Handling the rigor of college coursework requires personal discipline. For many students, college is their first experience managing their lives and responsibilities on their own. This can be stressful, resulting in them showing signs of being overwhelmed. Scott (2008) noted, "One of the most commonly felt consequences of college stress, is a feeling of being overwhelmed" (p. 2). Stress can also appear in other forms. For example, Brogaard (2012) identified achievement anxiety as a predominant cause of academic stress. Achievement anxiety is described as, "A fear of failure in an 
academic setting that arises when parents, teachers, or the student's own expectations exceed what the student believes she can realistically achieve" ( $p$. 1) (Brogaard, 2012). This is especially true when students fear losing a scholarship or are in other academic danger. Brogaard also identified involvement in college athletics, and sleep deprivation as major reasons for academic stress.

Family/ Employment/ Personal issues - Family and employment obligations can be additional areas of stress for students. Trouble in those areas can easily spill over into the academic arena. There are competing concerns in students' lives outside of their academic concerns. At any given point, students can be dealing with changing family dynamics, or experiencing changes in their own personal relationships. These changes often require them to strike a compromise in order to bring a balance to their lives. Due to marriage and family obligations, women are more likely to compromise their academics and career decisions. This view is highlighted in a study by Smith et al (2012), which examined educational factors related to delaying girls' marriage.

Health Challenges - Students who are dealing with unmanaged mental or emotional health concerns can be difficult to deal with. Such students can be threatening at times, and blatantly disruptive. They present major challenges for faculty who are not equipped to engage them, and they can bring dread to the experience of being a college professor. Futo (2011) noted that finances, relationships, mental health issues, and so on, all contribute to someone being pushed to the edge when combined with the pressures of papers, exams, and deadlines.

Ebbeling and Van Brunt (2010) asserted, "College Professors aren't law enforcement officers. They aren't expected to be entertainers or handholders. They do have the responsibility to create a classroom setting that engages students and fosters relationships based on mutual respect" (p. 2).

Additionally, some students have disabilities and other health concerns which do not cause disruptive behavior per se, but which causes faculty to be intentional about their sensitivity to such students in order to accommodate their needs and to comply with Americans with Disabilities Act (ADA) requirements. Rust and Sinelnikov (2010) conducted a study, which examined the professional preparation needed to teach students with disabilities. The study provides salient guidance on engaging such students. In spite of the available information on how to address these challenges, an adverse reality still remains in the fact that while there are often many campus-wide support services for students with emotional and physical needs, an increase in training to support and equip faculty who work with these students on a regular basis is lacking.

\section{STRATEGIES FOR ENGAGING STUDENTS AND REDUCING VOLATILE INCIDENCES}

In order to reduce adversarial relationships between faculty and students, with proper training, faculty should be able to take the lead in making sure that the integrity of classroom engagement and the level of professionalism are at high standards. Faculty must provide students with challenging engaged-learning activities and the curriculum should emphasize integration of higher order thinking skills, authentic tasks, and collaborative grouping (Conrad \& Donaldson, 2004).

Engaged learners are ultimately responsible for their own learning; however, some of them may not possess abilities required for taking responsibility, or may not be familiar with the steps for doing so. Faculty must therefore guide them in the process. The following are a few strategies faculty may use to improve engagement and reduce volatile incidences with students:

State expectations upfront - The value of a comprehensively written syllabus cannot be overstated. However, to have a well-written syllabus is not enough, faculty must also spend time at the beginning of the semester reviewing salient points and calling to students' attention those things that will be essential to their performance. There should be a calendar of events, especially in online courses, which shows due-dates and times for each assignment, and clearly stated grading policies. Any penalties for submitting unexcused late assignments should be clearly outlined and grading rubrics should be publicized and used in grading all assignments.

These measures inform students about what to expect, gives them the opportunity to be as prepared as possible, and creates a concise record for future reference. While these efforts may not eliminate all difficulties with students, they will lessen any substantive opposition from them. Most impor- 
tantly, they will eliminate ambiguity and provide a clear understanding of the terms of engagement for the course.

Focus on changes in behavior rather than beliefs - Faculty and students bring their own set of beliefs and perspectives to the learning environment. If those beliefs and perspectives are to change, it must be at the student's desire and not as a result of faculty coercion. The role of faculty is to facilitate learning. In the process of facilitating learning, beliefs and perspectives may change, but they should not be changed because of undue manipulation by faculty or anyone else. An approach implemented by Bright et al (2012), which was based on a shared leadership model proved to be rather successful. It demonstrated that student buy-in in the classroom makes a big difference in the way they behave. Dodge et al (2007) also found the use of behavior contracts to be quite effective.

While these strategies have proven successful in eliminating inappropriate behaviors from the learning environment, they cannot replace the value of a well-written syllabus, which addresses the issue of class etiquette. The etiquette statement might address how certain infractions will be handled. Infractions may include such things as: chronic absenteeism, including in online courses, disrespect for the faculty and other students, plagiarism and other areas of academic dishonesty, grade disputes, malicious use of profanity, persistent disruptions, and so on. However, while students should be required, within reason, to comply with class etiquette in order to be successful, their personal beliefs about those etiquettes are their business and may remain unchanged beyond the class.

Model expectations - Faculty should not expect students to exhibit high standards of behavior while theirs are low. For example, in online courses, faculty who have minimal interaction with the course, providing no input in discussions should not expect students to accept reduced class-participation grades. Rather, students should be able to see faculty modeling the expectations they have for them. It might also be helpful if the faculty can frame their behavioral expectations for students in the context of the student's overall preparation beyond the classroom. Students respond better when it is clear to them that the behavioral habits they are required to practice in the classroom are identical to those required in their desired career fields. For example, Furman and Sibthorp (2013) found that experiential learning approaches can be helpful in fostering learning transfer, whereas more didactic approaches seems to do the opposite.

Make instruction relevant - Enright (2012) emphasized the importance of making instruction relevant. The author provided strategies, which may be used in today's ethnically and linguistically diverse classrooms. The need to make instruction meaningful and engaging to students from vastly different backgrounds was emphasized. Smith (2013) found that connecting classroom learning to out-of-class learning can significantly enhance student performance.

When students skip class for no good reason, and return with that irritating question, "Did I miss anything important?" despite what the professor thinks, this can be a loaded question and may provide insight into how students feel about the class. If it were a highly valued class, the answer to their question would be obvious. If it is not highly valued, but rather hit-or-miss in terms of content, the question may actually be an expression of that feeling. When students are highly engaged and instruction is related to their life experiences, they are less likely to skip classes for no good reason. As facilitators of learning rather than "sages on stages", faculty must engage students in active learning, and inquiry-based activities, to which they can easily identify.

Do the simple things - A few words from the theme song for the TV Sitcom "Cheers" says, "Sometimes you want to go where everybody knows your name, and they're always glad you came." This should be true about the classroom. Faculty should make every effort to learn the names of their students. This could be a problem in large lecture classes, but somehow efforts should be made by the faculty through assigning various student-led assignments to reduce large lecture classes into cell groups. This makes it easier for students to get to know each other and for the faculty to get to know them. This strategy will also apply to online courses. It provides an element of accountability and contributes to the likelihood that they will complete the course.

The more familiar faculty are with their students from having spent time talking to them and getting to know them, the less likely they are to have behavioral and adversarial problems with 
each other.

Give thorough feedback - Feedback is important to students and their success. Too often students are required to transition from one learning unit to another without receiving appropriate feedback. This can be an added area of friction between faculty and students, especially in courses that are taught online. The need to provide timely and concise feedback cannot be overstated. Well written rubrics, which define assessment policies and scores for every aspect of each assignment, should be an integral part of the assessment process. To maximize performance, rubrics should be accessible to students prior to them engaging in any assessment exercise. Well-written rubrics reduce ambiguity and mitigate any substantive opposition to assigned grades.

Reflection can be an important aspect of feedback. White (2012) observed that reflection covers both the cognitive process and the broad range of activities that enhance learning resulting from experience. The opportunity to reflect on activities allows faculty and students to get a sense of each other's expectations and reduces the likelihood of bigger problems later. It provides students with information about where they went wrong and to see how they might improve moving forward. More importantly, it provides faculty the opportunity to assure students that they are advocates for their success and not obstacles to it. If students can come to view faculty as partners in their journey to academic and then career success they will be more likely to appreciate them and the level of difficulties between them will be minor.

Provide ongoing communication - If a well written syllabus is provided to and discussed with students, and if appropriate ongoing feedback is given, students who fail a course should not be caught by surprise. Evert et al (2013) found that there are positive relationships between students' perceptions of faculty communications and their own motivation.

Apart from cases where students blatantly attempt to misrepresent their performance, difficulties occur because of a lack of communication and clear assessment feedback. Students need to have ongoing feedback about their performance. This can be significant because the most important course outcome for students is their grade, and too often when that outcome is not good students are surprised, disappointed, and at times hostile.

\section{SUMMARY}

The college classroom is made up of students with various emotional dispositions and backgrounds. Like any other social setting, there will always be those who attempt to bend the rules in their favor and/ or use adverse tactics to redirect the focus to, or away from themselves depending on the circumstances. While careful training and planning may not totally eliminate every area of conflict, the strategies provided for engaging students and reducing volatile incidences have proven successful. Giancola et al (2008) make it clear that these strategies are especially successful among faculty who make it a priority to get to know their students, and to understand their backgrounds. Most importantly, these strategies demonstrate to students that faculty are genuinely interested in their success; hence, the likelihood of explosive confrontations are greatly reduced.

Finally, colleges may want to consider assisting students with their transition to higher education by imposing mandatory orientations to familiarize them with the expectations of college life, and instruct them on how to interact with faculty and staff. 


\section{REFERENCES}

Alvarez, H. (2007). The Impact of Teacher Preparation on Responses to Student Aggression in the Classroom. Teaching and Teacher Education, 23(7), 1113-1126.

Bright, D., Turesky, E., Putzel, R., \& Stang, T. (2012). Professor as Facilitator: Shaping an

Emerging, Living System of Shared Leadership in the Classroom. Journal of Leadership Education, 11(1), 157-176.

Brogaard, B. (2012). Academic Stress and Its Relation to Anxiety in College. Demand Media, Inc. Accessed May 31, 2012 at: http://www.ehow.com/about_6663520_academic-relation anxiety-college-students.html\#ixzz1urVcOX39

CETL, UM-Mankato (2005). Academic Dishonesty. Minnesota State University - Mankato. Accessed May 31, 2012 at: http:// www.mnsu.edu/cet//teachingresources/articles/academicdishonesty.html

Chase, A. (2010). Academic Dishonesty in Online Courses: The Influence of Students' Characteristics, Perception of Connectedness, and Deterrents. ProQuest, Florida Atlantic University UMI Dissertation Publishing. Accessed April 4, 2014 at: http:// search.proquest.com/docview/231229101

Conrad, R., \& Donaldson, J. (2004). Engaging the Online Learner. Jossey-Bass, San Francisco, CA.

Counseling Center at Brookhaven College (2011). Classroom Management: Dealing with Difficult Students. Dallas Community College District. Accessed May 31, 2012 at: http://www. brookhavencollege.edu/studentsvcs/counseling/classroommanagement.aspx

Dodge, D., Nizzi, D., Pitt, W. \& Rudolph, K. (2007). Improving Responsibility Through the use of Individual Behavior Contracts. Access July 17, 2014 at: http://files.eric.ed.gov/fulltext/ ED497427.pdf.

Ebbling, J. \& Van Brunt, B. (2010, March). Four Tips for Dealing with Difficult Students. Faculty Focus, Magna Publications. Word Press.

Enright, K. (2012). Making it Matter: Relevant Instruction for New Mainstream Students. Kappa Delta Pi Record, 48(2), 67-71.

Evert, A., Blackwell, C., Tilley, D., Weckler, P., \& Holcomb, R. (2013). Students' Perceptions of Communications and Course Motivation Provided by Faculty. Natural Sciences Education, 42(1), 91-97.
Furman, N., \& Sibthorp, J. (2013). Leveraging Experiential Learning Techniques for Transfer. New Directions for Adult and Continuing Education, 137, 17-26.

Futo, J. (2011). Dealing with Mental Health Issues on Campus Starts with Early Recognition and Intervention. Campus Law Enforcement Journal, 41(3), 22-23.

Giancola, J., Munz, D., \& Trares, S. (2008). First-versus continuing-generation adult students on college perceptions: are differences actually because of demographic variance? Adult Education Quarterly, 85, 214-228.

Harward, D. (2008, April). A Different Way to Fight Student Disengagement. Inside Higher Ed. Accessed May 31, 2012 at: http://www.insidehighered.com/views/2008/04/15/ harward\#ixzz1tjxxETRM

Northwest Regional Educational Laboratory (2005). Student Motivation. Focus on Effectiveness, Portland OR.

Pallof, R., \& Pratt, K. (2007). Building Online Learning Communities. Jossey-Bass, San Francisco.

Radosevich, D., \& Kahn, P. (2006). Tablet Technology and Recording Software to Enhance Pedagogy. Innovate, 2 (6). Accessed May 31, 2012 at: http://www.innovateonline.info/.

Rust, R. \& Sinelnikov, O. (2010). Practicum in a Self-Contained Environment: Pre-Service Teacher Perceptions of Teaching Students with Disabilities. Physical Educator, 67(1), 33-45.

Scott, E. (2008, August). Stress in College: Common Causes of Stress in College. Accessed May 31, 2012 at: www.ehow. com/about_6663520_academic-relation-anxiety-college students.html\#ixzz1urVcOX39

Smith C., Stone, R., \& Kahando, S. (2012). A Model of Women's Educational Factors Related to Delaying Girls' Marriage. International Review of Education, 58(4), 533-555.

Smith, F. (2013). We're All Going to the Zoo Tomorrow... Primary Science, 126, 23-26.

UC Berkley, Teaching, Learning, Academic Planning and Facilities, (2009). Problem Students and Disruptive Behavior. University of California, Berkley. Accessed May 31, 2012 at:http://teaching.berkeley.edu/teaching.html

U.S. Department of Education National Center of Education Statistics (2009). Distance Education at Degree-Granting Postsecondary Institutions. 2006-2008 NCES 2003-017. Accessed May 31, 2012 at: http://nces.ed.gov/pubs2009/2009044.pdf.

White, J. (2012). Students' Perception of the Role of Reflection in Leadership Learning. Journal of Leadership Education, 11(2), 
140-157.

\section{Author Biographies}

Ian Toppin currently serves as Director of the Center for Teaching and Learning (CTL) at Fort Valley State University, in Fort Valley Georgia. $\mathrm{He}$ is also Director of the institution's Quality Enhancement Plan (QEP), which focuses on enhancing critical thinking. He is the founding program chair for the online BS degree in Organizational Leadership. Dr. Toppin has over 23 years of higher education experience in the classroom and as an administrator. His areas of research interests and publications are in educational technology, computer virtualization, instructional technology, and instructional pedagogies. He received a Bachelor of Science degree from South Carolina State University, Master of Science from Illinois State University, Master of Arts from Luther Rice University, and Doctor of Education from the University of Georgia.

Laveda Pullens is an Evaluation and Assessment Specialist with the University System of Georgia Board of Regents (BOR). She works with the BOR colleges and universities training faculty on the latest version of the state teacher and leader evaluation systems and how to integrate these systems into the educator preparation curriculum. Dr. Pullens has also worked as a Coordinator of Academic Assessment with the University of North Georgia and was a Program Director and Instructor with the Technical College System of Georgia. She has held the position of Assistant Professor in the College of Professional Studies at Clayton State University and continues to work as an Adjunct Associate Professor at the University of Maryland at Maryland College. She obtained her Doctorate and Masters in Education Degrees from the University of Georgia. 